\title{
The Impact of Text Messaging as an Instructional Tool to Enhance Learner Autonomy and Perception
}

\author{
Behnam Behforouz and Anca Daniela Frumuselu \\ Universitat Rovira i Virgili, Spain \\ https://orcid.org/0000-0002-0078-2757 \\ https://orcid.org/0000-0003-4395-7841
}

\begin{abstract}
This paper investigates the efficiency of text messaging as an English as a Foreign Language (EFL) instructional tool to enhance learner autonomy and perception at the Islamic Azad University-South Tehran Branch, Iran. The study considers seventy-four learners to participate in the study after the administration of an Oxford Placement Test to measure their proficiency level. Participants are randomly assigned in experimental and control groups, including 37 participants each. A questionnaire is used as a pretest and posttest to measure learners` autonomy. Participants from the experimental group use text messaging (the treatment) to receive instructions, whereas those from the control group receive traditional classroom instructions in a face-toface channel. A semi-structured interview is also used to collect date on experimental group participants' perception in using MALL in classrooms. The results reveal remarkable differences between the experimental and control groups' means on their learner autonomy scores. However, the impact of the independent samples t-test has shown that there is no statistically meaningful gender difference among the learners regarding their autonomy scores. The findings based on the semi-structured interview showed complimentary views on MALL. The current study is beneficial since its outcomes could be relevant for EFL curriculum developers and English language teachers in the use of mobile learning and text messaging in the English classroom.
\end{abstract}

Keywords: Text Messaging; EFL; Learner Autonomy and Perception; MALL

\section{Introduction}

Interest with the manifestation of communication technology, different aspects of life, including language learning systems, have been changed. This change is produced by communication technology, young people, and the worldwide use of the English language, Buckinghamas (as cited in Hazaea \& Alzubi, 2018). In technology development, the mobile phone is commonly used worldwide. The 
flexibility and the other characteristics, such as size, cost-effectiveness, and userfriendliness, are among the benefits of mobile technology. Since phones have gained strengths, they are inexpensive and easy to use, then, the study of mobile-assisted language learning (MALL) changes to be a required field of study. Due to its popularity, it is not rare that it is used as a learning tool.

In this respect, mobile phones are used for different personal objectives, and they can transfer the learning process to a more interesting one while acquiring other language skills. As such, there is a shift in learning context from traditional to digital by emerging technological development such as mobile phones, tablets, pods, pads, personal digital assistants, electronic pocket dictionaries, MP3 players, and other portable devices (Fredrick \& Karthikeyan, 2018). The capabilities of these devices are being developed in educational contexts day by day. Regardless of the place and time, their mobility, accessibility, and applications have made them useful in promoting learning. Among other moveable technological devices, cell phones are the most universally functional platform in the educational process. Some research studies have been done based on using mobile phone devices for educational goals, and they have revealed a gradually increasing use among learners (Johnson \& Radhakrishnan, 2017; Ng, Hassan, Nor \& Malek, 2017; Patel, 2013; De la Fuente, 2014; Ducate \& Lomicka, 2009).

With regard to the above said, successful foreign/second language learning process requires interaction with people and communication in the target language. In other words, learner's foreign language skills are strengthened when learners cooperate and interact with others. These interactive and cooperative aspects of learning have been focused due to the rapidly growing interest of the current generation of EFL learners in a digital world. Using mobile phones is an excellent part of their daily experience outside of educational contexts (Ivić \& Jakopec, 2017; Cavus \& Ibrahim, 2009, Beland \& Murphy, 2016).

Utilizing mobile learning (m-learning), learners can experience multimedia learner-centred learning with various activities and enjoy a more interactionfocused learning process. M-learning gives learners the ability to experience the real world's feelings and emotions via interacting with the real environment, learning materials, and increasing their learning motivation and interest (Huang, Jeng \& Huang, 2009; Liu, 2009). It should be mentioned that m-learning is not a substitute for today's existing learning tools and techniques, but is an extension for learning in a new context with modern capabilities. The learners' knowledge, skills, and attitudes toward m-learning are very significant because the output quality relies on it. Therefore, MALL is considered as a compelling way to learn a language for a non-native person (Krishna, 2020).

Among the different types of mobile communication, texts messaging and instant messaging are practical in educational institutions. By definition, text messaging or texting is a two-way communication among the phones users through some short, typed messages, so-called short message service (SMS) (Kasesniemi \& Rautiainen, 2002). Because texting is used pervasively among 
learners (Johnson, 2007; Smith, Salaway \& Caruso, 2009), Rahamat et al. (2012) showed that learners whose teachers sent some text messages stayed motivated in the learning process. They were very interested in continuing learning since they had the sense of being appreciated and accepted. Based on this finding, all human activities are arbitrated through culturally defined or created signs or instruments that the 'subject' (person) interchanges with the 'object' (lesson content) via the application of the mediating devices (mobile technology) to gain the 'outcome' (goal) (Cowan \& Butler, 2013).

Considering the resources, opportunities, and collaboration, the process of teaching in the $21^{\text {st }}$ century is regarded as an inspiring activity. The portability of mobile phones has enabled learning independent of place and time, even outside the classroom. In fact, in this digital century, Mobile Assisted Language Learning (MALL) has become a good way to support the growth of learner autonomy (LA) in English as a foreign language (EFL) context. It has been claimed that learners who are exposed to EFL learning materials can use their smartphone properties, applications and apply learning strategies on their own in an independent learning context to promote autonomous learning skills, and consequently enhance their language competence (Alzubi, 2019; Pollara \& Broussard, 2011; Fabian, Topping \& Barrons, 2018). Therefore, this study aims to investigate the implementation of text messaging in Iranian EFL university students' abilities in learning a foreign language.

Regarding gender, some of the research studies have found some gender differences in mobile technology usage in some national and cross-cultural contexts (Hijazi-Omari \& Ribak, 2008; Baron \& afSegerstad, 2010). A study carried out by Wang, Wu \& Wang (2009) who examined the factors dealing with m-learning acceptance to investigate age or gender differences. 330 participants were studied in this research, which was done in Taiwan. The findings showed that age and gender differences moderate the effects of social influence on the intent of using m-learning. Previous research studies on MALL have tended to find learners' perceptions of the mobile device functions and its function in education (Kim, Rueckert, Kim \& Seo, 2013; Stockwell, 2010), yet few studies have investigated learners' perceptions regarding the usage of a mobile device in an educational context. To fill this gap, this present study aims at answering the following research questions:

RQ1: Are learners more autonomous in their learning after using text messaging as an instructional tool?

RQ2: Is gender a distinguishable variable in autonomy after using text messages?

RQ3: How do learners perceive the use of MALL in the EFL learning context?

Based on the above-mentioned research questions, the following null hypotheses are put forward:

H01: The Iranian EFL learners are not more autonomous in their learning after using text messaging as an instructional tool.

H02: Gender does not have any significant effect on the learner's autonomy after employing text messages. 
H03: Learners perceived mobile devices as beneficial tools to improve the teaching and learning processes to a great extent.

\section{Literature Review}

Researchers conducted a significant number of discussions and empirical studies on learner`s autonomy and learner`s perception (Little, 1991; Min \& Borg, 2018; Tran \& Duong, 2018; Yunus \& Arshad, 2015). In light of the posited research questions, this section reviews the existing literature and presents theoretical background on learner autonomy and MALL perception in an EFL context.

\subsection{The Concept of Learner Autonomy}

It can be observed that no general agreement does exist on the learner autonomy among the linguists and the educators. Considering the existing literature, there is the dichotomy of autonomy and independence, each having its own advocates. In this respect, Little (1991) argues that learner autonomy focuses on interdependence over and above independence; and, Dickinson (1994) relates autonomy to the concept of learning by taking active responsibility for one's learning. Further, Dickinson (1994) defines autonomy as an independent capability that works with the language to communicate personal concerns in real and unpredictable situations. Therefore, language learners need to have the capacity to read between the lines rather than reading the lines while autonomously completing their education. One of the most influential definitions is the one given by Holec (1981), in which he defines learner autonomy as the learners' abilities to take responsibility for their learning. Meanwhile, it includes learners' decision-making while learning, particularly in setting learning goals, specifying content and progress, selecting learning methods, monitoring, and assessing learning. It indicates that learners are free to plan and control their learning by choosing what, when, and how to learn following their interests, essentials, and capabilities.

As Benson and Voller (1997) state, learner autonomy is suggested to be functional in the following five modes: 1) situations where learners study entirely on their own; 2) a set of skills which can be learned and used in the selfdirected learning; 3) an inborn capacity which is suppressed by institutional education; 4) the exercise of learners' responsibilities for their learning; and 5) the right of learners to determine the direction of their learning. Dickinson (1995) asserts that learner autonomy is a learning behaviour or mechanism, including a learning attitude and an independent learning ability. He refers to attitude as the learners' responsibility to make decisions for their learning and capability as the reflection on decision-making and learning.

\subsection{MALL and Learner's Autonomy}

According to Sung, Chang and Yang (2015), implementing a mobile phone in language learning contexts can increase the learners' autonomy levels. They mentioned that mobile phones could be helpful for some reason. The primary reason is that by using mobile phones, learners can easily control their own learning. That is to say, learners can use this option to self-direct and personalize their learning process with the appropriate learning speed, without time and place restrictions. The second reason for using mobile phones is that they help 
students interact and collaborate with their teachers and classmates easily; thus, such collaboration can help learners to expend attention, metacognitive abilities, and reflection. Thirdly, mobile phones allow students to have easy and selfaccess to educational materials designed by the teachers.

In a study by Sato, Murase and Burden (2015), ninety-seven undergraduate students were participated to measure the effect of mobile-assisted language learning on the learner's autonomy. The findings of the study reveal that MALL helps the learners to remember the target language better. Although their questionnaire results are not so remarkable, they concluded that MALL could increase the level of motivation in students learning vocabulary capabilities. In another study by Ramamuruthy and Rao (2015) on seventy students of International College of Automotive (ICAM), based on using mobile phones and the number of learners` autonomy, it has been revealed that the usage of these devices fosters the learners`autonomy to a certain extent.

In the same vein, Purwaningrum and Yusuf (2019) studied thirty Indonesian graduate students to measure MALL's practicality on learners' autonomy. Results indicate students' satisfaction towards implementing MALL in the educational process, which leads to objectives accomplishment, and learners autonomy enhancement as well.

\subsection{Promoting Learner Autonomy and EFL Teaching}

In EFL research studies, learner autonomy plays a central role. Current school curricula and educational paradigms inspire pedagogy for autonomy (Council of Europe, 2001). Accordingly, plenty of scholars have promoted its development, but few have investigated its practice (Benson, 2011; Dam, 2011; Dickinson, 1995; Little, 2007; Miliander \& Trebbi, 2011; Trebbi, 2011). It is also crucial to record that teachers play a significant role in the autonomous learning environment as learner's autonomy relies on teachers who initiate an educational context where autonomy is admitted. In the same context, Camilleri (1999) mentions some attributes that teachers must consider in an autonomous learning exposure involving pedagogical realization, self-awareness, and classroom management techniques.

Little (1995) asserts that it is hard for learners to accept their learning responsibilities in such a new autonomous-type learning environment. Therefore, teachers need to motivate the autonomy of their learners inside of the class. Nunan (1997) discusses that encouraging learners' autonomy has some stages: awareness, involvement, intervention, creation, and transcendence. In the first level, which is awareness, students will be familiarized with the course objectives and materials. In the involvement level, students choose their aim from a variety of available alternatives, and in the next stage they improve and adjust the course objective and content. In the following step, students form their own goals and finally, students use the course content in the authentic settings. 


\subsection{Learners' Perception of MALL}

In fact, the field of education has been revolutionized through the manifestation of technology. The application of technology in developed countries in educational institutions and classrooms is becoming a systematic practice. Kim, Ruecker, and Kim (2017) attempt to explore the advantages of learning via cell phone for TESOL learners, and to investigate their learning insights with such a sort of technology. The study recommended effective instructional strategies, continuous technical support, and assistance through professional development training. In another context, Azli, Shah and Mohamad (2018) conducted a study to determine the perception of the application of MALL in ESL college students. The required data were collected through the administration of a Technology Acceptance Model (TAM) questionnaire. The findings showed the positive attitudes of the participants in using MALL. More than that, most of the respondents indicate general agreement on both perceived ease of use (PEoU) and constructed perceived usefulness (PU) of MALL. They believed that the practice of MALL could improve the process of teaching and learning.

In another study, Dehkordi and Taki (2018) examined the perceptions of ninety Iranian EFL learners on MALL usage. The study's goal is to find the discrepancies among the Iranian male and female EFL learners' perceptions towards MALL. The study also attempts to reveal the difference between the mobile learning capabilities of the learners. To collect the required data, Mobile Learning Perception Scale that is developed by Uzunboylu and Ozdamli (2011) was used. The findings reveal no remarkable gender difference between Iranian learners in the m-learning process. Both genders had positive attitudes on $\mathrm{m}$ learning and technology-based language learning. Considering the studies mentioned above, there is consistent evidence that learning issues related to learner autonomy and learners' perception of MALL use are influenced not only by mobile phones in general, but also by the involvement with different aspects (e.g., text messaging, SMSs, ...) of these instruments.

\section{Methodology}

This section is meant to present the method used to design the study and how data collection has taken place. In hope to meet the objectives of the present study, an experimental design with the total procedure of sampling, instrumentation, data collection, and data analysis are explained in the following sub-sections.

\subsection{Participants}

A number of eighty-eight undergraduate university students with different majors (Chemistry, Civil Engineering, Computer Science, and Electrical Engineering) studying General English at the Islamic Azad University-South Tehran Branch, Iran voluntarily have participated in this study. To measure the participants' general English proficiency level and to ensure their homogeneity, an Oxford Placement Test (OPT) is administered. After the OPT, a number of seventy-four students (48 females and 26 males) within the age range of 21 to 26 years old who scored between 28 and 36 points (pre-intermediate level) were selected as the study participants who randomly assigned into two groups, i.e., an experimental group and a control one, each including 37 research informants. 
They were all Persian native speakers and all of them had a mobile phone to use for the study.

\subsection{Instruments}

To begin with, an Oxford Placement Test (OPT) was conducted before the treatment to measure the group's homogeneity and if learners had a similar proficiency English level. The allocated time to complete the test is 55 minutes. This test consists of two parts with 60 multiple-choice items and close questions. The first part consists of 40 questions and the second part consists of 20 questions. Participants were required to read the items and then choose the correct answers among the choices. According to the test norms, the participants' scores are ranked in 6 levels, from beginners to advanced levels. Table 1 shows the OPT ranking. The sample of the current study is selected based on learners lower-intermediate scores; thus, all the students who scored between 28 and 36 points were considered viable participants for the present research.

Table 1. Oxford placement test ranking

\begin{tabular}{|l|c|}
\hline \multicolumn{1}{|c|}{ Levels } & Range of the scores \\
\hline Beginner & $1-17$ \\
\hline Elementary & $18-27$ \\
\hline Lower-Intermediate & $28-36$ \\
\hline Upper-Intermediate & $37-47$ \\
\hline Advanced & $48-55$ \\
\hline Very Advanced & $56-60$ \\
\hline
\end{tabular}

As far as participants' autonomy is concerned, the 21-item questionnaire designed by Zhang and Li (2004) is used to measure this variable. To calculate the questionnaire's internal reliability that Zhang and Li calculated, Cronbach alpha is therefore used, which turned out to be 0.89 . This questionnaire consists of two parts; one part has 11 items through a 5-point Likert scale, which is coded as (A. never; B. rarely; C. sometimes; D. often; E. always), while the second part includes 10 . The second part of the questionnaire is in a multiple-choice format. The Likert-type items are generally considering the principles of learner autonomy in real language learning contexts. In the contrary, the second part of the questionnaire contains 10 forced-choice format items, i.e., there is no 'non response' type choice, such as "no idea," "don't know," "not sure', which examines learners' perceptions towards concepts of learner autonomy in depth. To change the participants` selections to numerical data, the options A, B, C, D, and $\mathrm{E}$ are marked one, two, three, four, and five, respectively. 105 is considered as the total mark. The participants were asked to respond to each item, selecting one option among the others. The autonomy questionnaire is administered twice, as the pretest and posttest, to determine the differences between learners' autonomy towards implementing MALL as an instructional tool before and after the treatment. 
The third instrument is a semi-structured interview prepared and administered to the experimental group by the researchers, including seven open-ended questions that treat the aspect of MALL and SMS text messaging in the EFL classrooms. These items are designed to motivate a full, meaningful answer through the participant's own knowledge and/or feelings. It should be mentioned that open-ended questions are often more objective and less leading than closed-ended ones. Considering the theoretical background and types of questions that the interviewer required to ask, some of the questions were developed in advance (Lindlof \& Taylor, 2002). The purpose of the interview is to understand learners' perceptions of MALL and mobile phone usage for English learning.

To ensure the relevance of the questions to the study's purpose, two EFL teachers validated the questions. They were asked to determine whether questions are relevant with respect to the objectives and whether they are clearly and coherently formulated. They were also requested to jot down some comments on the questions if necessary. The comments given have assisted the investigators to delete and revise some questions. Finally, researchers selected seven questions for the interview to indicate their opinions freely (see Appendix 1). After the treatment procedure, the experimental group participants who were exposed to SMS text messaging over a period of six weeks took part in a face-toface interview. The interviewer asked the questions, and the learners were asked to state their perceptions, feelings, and opinions about the use of MALL in EFL classrooms.

\subsection{Procedures}

The researcher administered the OPT initially to ensure the participants' homogeneity prior to the treatment's commencement. Regarding the scoring agenda in OPT, it should be mentioned that each right answer scored as plus one, and there was no negative point for any incorrect or unanswered items of the test. During the reading course in the fall semester of the academic year 2019-2020, the study is carried out over an 18-session treatment during six successive weeks (the participants in the experimental group would receive SMSs three times a week). The same teacher took the responsibility of teaching both groups. The researcher used text messaging to improve learners' autonomy and determine their perceptions toward MALL in the language learning context.

The second step is devoted to the administration of the 21-item autonomy questionnaire as the pretest for learners of both groups to delve into the EFL learners' hidden layer of opinions and attitudes because scholars believe that questionnaires are the most efficient and economical means of eliciting information (Denscombe, 2014). After finishing the treatment process, the learner autonomy questionnaire is administered for the second time as a posttest to check SMS text messaging effectiveness as the treatment procedure. As a final step, the teacher interviewed the learners in the experimental group to investigate interviewees' perceptions of MALL. Since the semi-structured interviews provide more areas for the participants to give out their views on the subject matters (Cohen, Manion \& Morrison, 2011), the interview was carried out through a face-to-face session in English. The interview took about 5-10 minutes, 
and the learners are interviewed individually. Students are required to talk about their own previous MALL experience, their feeling about text messaging in vocabulary learning, the usefulness of text messaging in EFL classrooms, their ideas about the future implementation of text messaging in EFL learning, and the possible challenges while using text messaging in the EFL classes.

\section{Data Analysis and Findings}

This section deals with the analysis and the interpretation of collected data. After collecting the data from the research instruments, descriptive analysis is then carried out focusing on the basic features of the data, and inferentially, trying to reach conclusions that extend beyond the immediate data alone. To investigate learners' autonomy and perception towards the use of MALL after being exposed to English learning using text messaging via mobile phones, the quantitative data are analyzed with the Statistical Package for Service Solution (SPSS) program. In order to have homogenous participants based on the General English language level, the OPT was administered, and 74 participants were considered homogenous based on their OPT scores, which ranged from 28 to 36 points that would correspond to the pre-intermediate level or B1 level, according to CERF. Table 2 reveals that the mean and the standard deviation of the homogenized participants are 31.66 and 2.22, respectively. This reads that most of the numbers are close to the average; therefore, participants' scores show that they have a homogenous general English proficiency level in the experimental and control groups.

Table 2. The descriptive statistics of the homogenized participants

\begin{tabular}{lllllll}
\hline & $\mathrm{N}$ & Min & Max & Mean & SD & V \\
\hline Homogenized & 74 & 28.00 & 36.00 & 31.66 & 2.22 & 4.96 \\
Valid N (listwise) & 74 & & & & & \\
\hline
\end{tabular}

To answer the first research question, an ANCOVA test is run on the learners performance in the autonomy questionnaire by Zhang ad Li (2004) to compare the autonomy scores between the two groups. In this concern, Table 3 shows the descriptive statistics for the autonomy scores of both groups. Both groups' means related to the autonomy scores are 71.05 and 73.94. As can be seen, the standard of error (=.229) shows the standard deviation of the mean within the collected data; the smaller the spread is, the more accurate the dataset is.

Table 3. The descriptive statistics for the adjusted autonomy scores of the two groups

\begin{tabular}{lllll}
\hline & & & \multicolumn{2}{l}{$95 \%$ Confidence Interval } \\
\cline { 4 - 5 } Group_C_E & Mean & Std. Error & Lower Bound & Upper Bound \\
control & $71.052 \mathrm{a}$ & .229 & 70.596 & 71.507 \\
experimental & $73.948 \mathrm{a}$ & .229 & 73.493 & 74.404 \\
\hline
\end{tabular}

Table 4 below displays the result of the ANCOVA test. Based on the statistics, there is a statistically significant difference between the control and the experimental groups based on their autonomy scores, $F(1,71)=80.28, p<.05$, partial $\eta 2=.53$. The partial Eta Squared represents the effect size and is comparable with Cohen`s (1988) guidelines (0.2-small effect, 0.5-moderate effect, 
and 0.8-large effect). Therefore, the ANCOVA results indicate that there are significant differences between the two groups' means on their learner autonomy scores. Consequently, the first null hypothesis is rejected. That is to say, using text messaging as an instructional tool had a statistically significant effect on learners' autonomy.

Table 4. The result of the ANCOVA for the comparison of the autonomy scores

\begin{tabular}{lllllllr}
\hline & \multicolumn{2}{l}{ Type III Sum } & of & & & & \multicolumn{2}{l}{$\begin{array}{l}\text { Partial } \\
\text { Sta }\end{array}$} \\
Source & Squares & df & Mean Square F & Sig. & Squared & \\
\hline Corrected Model & $3227.284 \mathrm{a}$ & 2 & 1613.642 & 834.94 & .000 & .959 \\
Intercept & 8.641 & 1 & 8.641 & 4.47 & .038 & .059 \\
Pre-scores & 3042.297 & 1 & 3042.297 & 1574.17 & .000 & .957 \\
Group_C_E & 155.161 & 1 & 155.161 & 80.28 & .000 & .531 \\
Error & 137.216 & 71 & 1.933 & & & \\
Total & 392327.000 & 74 & & & & \\
Corrected Total & 3364.500 & 73 & & & & \\
\hline
\end{tabular}

The second research question aimed to answer whether gender had any statistical significant role in students' autonomy after receiving text messaging. Prior to the investigation of the second null hypothesis, the two groups (male and female) were compared to their autonomy scores. To check the assumption of normality, the Shapiro-Wilk test of normality is used. Assumption of normality means that it must be sure that the data roughly fit a bell curve shape before running specific statistical tests or regression. The Shapiro-Wilk test is based on the correlation between the data and the corresponding standard scores. The result of the Shapiro-Wilk test of normality in Table 5 reveals that the data are typically distributed for the two sets of scores (Sig>.05). It is worth mentioning that if the Sig. Value of the Shapiro-Wilk test is more prominent than 0.05 , then the data are considered normal.

Table 5. The result of the normality test for the scores of the males and females

\begin{tabular}{lllll}
\hline \multirow{2}{*}{ Post-scores } & & \multicolumn{3}{l}{ Shapiro-Wilk } \\
\cline { 3 - 5 } & Gender & Statistic & $\mathrm{df}$ & Sig. \\
& female & .976 & 26 & .776 \\
& male & .963 & 11 & .812 \\
\hline
\end{tabular}

After checking the normality of data, the independent samples t-test should be used for mean comparison. The descriptive statistics of the two groups are presented in table 6 . The mean and standard deviation of the females and males are $70.88,6.87$, and $71,5.89$, respectively.

Table 6. The descriptive statistics for the scores of males and females

\begin{tabular}{llllll}
\hline \multirow{3}{*}{ Post-scores } & Gender & $\mathrm{N}$ & Mean & SD & Std. Error Mean \\
\cline { 2 - 6 } & female & 26 & 70.884 & 6.877 & 1.348 \\
& male & 11 & 71.000 & 5.899 & 1.778 \\
\hline
\end{tabular}


The independent samples' t-test is run to measure the difference between the mean scores of female and male participants. Since the p-value is higher than the alpha level $(.96>.05)$ in Table 7 , it shows that there is not a meaningful discrepancy between the male and female participants regarding their autonomy scores $t(35)=.049, P>.05$. Therefore, it can be concluded that gender does not have any statistically significant role in the students' autonomy who received text messaging for six weeks, so the second null hypothesis is valid.

Table 7. The result of the independent samples t-test for the comparison of males and females

\begin{tabular}{|c|c|c|c|c|c|c|c|}
\hline \multirow{3}{*}{$\begin{array}{r}\text { Post-scores Equal } \\
\text { variances } \\
\text { assumed }\end{array}$} & \multicolumn{2}{|c|}{$\begin{array}{l}\text { Levene's Tes } \\
\text { for Equality o } \\
\text { Variances }\end{array}$} & \multicolumn{4}{|c|}{ t-test for Equality of Means } & \multirow[b]{2}{*}{$\begin{array}{l}\text { Std. Error } \\
\text { Difference }\end{array}$} \\
\hline & F & Sig. & $t$ & $\mathrm{df}$ & $\begin{array}{l}\text { Sig. } \\
\text { (2-tailed) }\end{array}$ & $\begin{array}{l}\text { Mean } \\
\text { Difference }\end{array}$ & \\
\hline & .632 & .432 & .049 & 35 & .962 & -.11 & 2.37 \\
\hline $\begin{array}{l}\text { Equal } \\
\text { variances } \\
\text { not } \\
\text { assumed }\end{array}$ & & & .052 & 21.911 & .959 & -.11 & 2.23 \\
\hline
\end{tabular}

The third research question sought to find how learners in the experimental group perceive the benefits and challenges of the use of MALL in EFL classrooms. To elicit learners' responses and their feelings about using MALL in their classrooms, a number of 7 open-ended questions were asked. The first interview question looked into learners' previous experiences of using MALL (e.g., Whats app, Telegram, SMS text messaging) in the EFL classroom. Out of 37 learners, 32 had no previous experience in EFL studies, and 5 had experience using MALL in their EFL classrooms.

The second question sought to find more details about learners' feelings when using mobile devices to work on their English vocabulary. A number of 28 learners mentioned that using text messaging was useful; while 5 learners find it not practical and the 4 respondents state that they have no idea.

For the third question, 24 learners considered MALL as useful and beneficial, and 13 others claim that the use of MALL is not helpful because they are concerned about the misuse of mobile phones. They also said that mobile phones are used for social or personal purposes, or for cheating instead of applying for educational purposes. Some state that the use of MALL might be useful in writing classes.

The fourth interview question deals with the learners' future use of text messaging for English learning. 19 participants utter that they feel text messaging would improve their foreign language learning skills, and the 
remaining ones say it would not improve, and it would definitely be faded away soon.

For the fifth interview question, a number of 27 participants in the experimental group stated that EFL classes using MALL are more attractive, exciting, and enjoyable, however, it depends on the content, the context, and the way it is being presented.

Considering the sixth question, a number of 20 learners stated that the use of MALL in EFL classrooms is more productive than without using it. They consider that due to the quick availability of the authentic materials from the World Wide Web, and it can be used immediately to enrich group discussions. On the other hand, 10 learners did not agree that the use of MALL in EFL classrooms is more productive. They highlight that technology could not be a replacement for the teacher because the impact of technology mainly relies on the appropriate selection, which aligns with the teaching and learning purposes.

The last interview question asked learners to talk about the difficulties they face while using text messaging in EFL classes. A number of 11 learners state that there is no problem using text messaging in EFL classes. Nevertheless, 26 learners point out some issues, such as the cost of sending messages that keep them from using text messaging as an instructional tool. Some believe that through text messaging, learners are not able to master or practice oral skills.

With regard to the above said, nearly all learners had previous MALL experiences in EFL studies. They used mobile phones before, while in the classroom, and after class times to support their learning. Plenty of the participants find the use of MALL for EFL tasks and activities as being advantageous, exciting, fun, and productive. While the vast majority the learners are concerned about using MALL in EFL classes, some of them perceived it as a distraction and as a threat when replacing the teacher, and/or as a tool that is not enhancing oral skills. As a whole, it can be inferred that the overall perception is positive, except a few cases that are concerned about the misuse of the tool in educational contexts.

\section{Discussion}

The present study aimed to address learners' levels of autonomy regarding text messaging and find out their perceptions of mobile devices in the EFL classrooms in Iran. The first research question concerns the difference between learner autonomy of EFL learners exposed to text messaging as an instructional tool and learner autonomy of those exposed to the traditional instruction. Based on the results, participants in both groups (experimental and control) showed a statistically significant difference, considering the level of autonomy. Indeed, integrating m-learning with traditional instruction can improve learner autonomy.

The results are consistent with a study carried out by Nasr and Abbas (2018), which examined the role of MALL in improving learner autonomy in the EFL reading context among students of Najran University in Saudi Arabia. The 
findings show that the learners' LA is increased using MALL to take responsibilities and make decisions regarding reading materials. The results of this study totally correspond with Hazaea and Alzubi (2018) who state that MALL can motivate the modes of learners and autonomous learning in the EFL context, presuming that they are presented by directions on the teachers' contact hours and free time in order to provide more chances of success and motivate more learner autonomy.

Moreover, findings on autonomy agree with those reported by Farangi, Kamyab, Izanlu, and Ghodrat (2017), which examined the impact of SMS on Iranian upper-intermediate EFL students' grammar learning. The findings indicate that the implementation of SMS had a major impact on Iranian EFL learners' grammatical knowledge, and the learners' autonomy is enhanced in their learning. The study's findings also align with what Leis, Tohei and Cooke (2015) report as an improvement in the awareness of the benefits that mobiles can provide for EFL learning. What is more is that learners have increased their learning outside the classroom in their private time and became more autonomous.

The second research question investigates whether gender had any statistically significant role in the students' autonomy who received text messaging. The results did not reveal a remarkable difference in the learner autonomy based on their gender in the experimental group. The findings of this study are in agreement with those reported by Lachane and Mazzocco (2006). They state that despite the differences between male and female learners, it can be concluded that autonomous learning strategy through technology is gender-friendly and engages learners' minds-on and hands-on-learning more than the conventional method. Although Abdel Razeq (2014) stated that there is a gap between the performance of learners, but the findings of the current study align with the results of the studies by Varol and Yilmaz (2010), and Mardjuki (2018) which reveal that there is no difference between the genders in learning activities and performances.

Considering the third research question, the interview results show that the respondents, who are EFL learners, perceive mobile devices as beneficial tools to improve the teaching and learning process. It can be concluded that the use of MALL in learning contexts gives learners safe access to various resources, provides them diverse activities in English, facilitates their communication and interaction with their teachers and friends.

The outcomes of the third research question are in accordance with those reported by Ali, Mahmood, Anwar, Khan, and Hussain (2019). They made an attempt to examine the Pakistani`s ESL learners' perceptions of MALL in English language classrooms. Findings read that learners have shown a positive tendency towards applying MALL inside the ESL classrooms. Similarly, White and Mills (2014), based on survey on Japanese students, find that the learners attitudes regarding the implementation of MALL in EFL setting is improving daily. 
Consequently, this paper contributes in the fields of MALL and EFL by providing meaningful insights into the areas of learner autonomy and learners' perception in the Iranian higher-level context. The results emphasize that using text messaging as an instructional tool allow students to experience new learning methods, more flexibility, learning choices considering language content, learning space, and time, that in turn improve their learning autonomy. The findings of the current study show positive perception and satisfaction of the studied participants in terms of using MALL in EFL classrooms.

\section{Conclusion}

The learner autonomy level depends on the different objective and subjective factors such as personality, age, educational system, etc. However, the main factor is the teachers and the learners' cultural background. This means that autonomy is idealism in some specific cultures, and the teacher has an important responsibility to improve it among the learners so that they can make a knowledgeable choice at various stages of the learning process. This central role of the teacher and some other factors, maintains the teacher-centred learning model at all stages. The current study had two main findings: 1) using text messaging as a medium to improve learner autonomy, and 2) gender did not have any role in the autonomy of the students who received text messaging during a period of six weeks.

The present paper leads to an understanding that text messaging affects Iranian EFL learners' autonomy and their sense of connectedness. Texting is an inseparable aspect of learners' lives; thus, it is crucial for the educational community to know if text messaging can be used as an instructional tool to improve educational achievements and if it is useful to develop and enhance learners' sense of autonomy. Based on the findings, it can be concluded that teachers and instructors should investigate ways to effectively incorporate learners' mobile phones and MALL methodologies in their classrooms. The useful form of implementing any instrument in language learning requires considerate application of L2 pedagogy, which helps learners to be no longer confined to the classroom environment; instead, they advantageously have improved their understanding outside the classroom.

It can be considered essential for the language teachers to implement and effectively use mobile learning in the class and model their use for learning in general, hoping that they will use their mobile phones outside the classroom. Helping learners to be aware of their natural and preferred learning style is useful, since it helps in motivating them to move beyond their comfort zone and try out various approaches to learning. Viberg and Grönlund (2012) stated that due to insufficient considerations of students' learning styles and strategies in $\mathrm{m}$ learning, more research studies are essential to investigate the area.

The findings also reveal that it is essential to develop new learning approaches and techniques in Iranian EFL exposures due to technology's insufficiency. The inclusion of MALL in an educational context will be inexpensive yet influential in creating qualified results for the teachers and learners as well. The time and place flexibilities will allow learners to be free from anxiety and mindful in their 
performances, so the learning process and monitoring will be more straightforward. Besides, the proper use of mobile-related technologies inside and outside EFL classrooms facilitate the process of teaching and learning and would be helpful for the learners to learn the language better and gain information in depth. In this vein, language teachers are able to create an appropriate environment for teaching by using technology. However, it should be mentioned that most of the Iranian teachers do not have the required skills for the implementation of MALL in EFL classes. Based on Tai and Ting's (2011) suggestion, educational organizations should be responsible in providing EFL teachers with information and communication technology (ICT) skills for successful MALL implementation in their teaching practices.

The main focus of the current study is on the vocabulary learning, SMS, and learner's autonomy, and therefore, further studies can be done on the role of SMS in other learning skills. Since, the pre-intermediate learners were the participants of this study, more research is suggested to be implemented with other proficiency levels for the purpose of comparison and wider effect measurements.

\section{References}

Abdel Razeq, A. A. (2014). University EFL Learners' Perceptions of Their Autonomous Learning Responsibilities and Abilities. RELC Journal, 45(3), 321-336. http://doi.org/10.1177/0033688214547035

Ali, M. M., Mahmood, M. A., Anwar, M. N., Khan, L. A., \& Hussain, A. (2019). Pakistani learners' perceptions regarding mobile assisted language learning in ESL classroom. International Journal of English Linguistics, 9(4) 386-398. https://doi.org/10.5539/ijel.v9n4p386

Azli, W. U. A. W., Shah, P. M., \& Mohamad, M. (2018). Perception on the usage of mobile assisted language learning (MALL) in English as second language (ESL) learning among vocational college students. Education, 9(1), 84-98. https:// doi.org/10.4236/ce.2018.91008

Alzubi, A, A, F. (2019). Smartphone-mediated language learning strategies and learner autonomy among pre-university learners in EFL reading context. Journal of Humanities and Social Sciences Studies (JHSSS), 1(3), 49-63.

Baron, N. S., \& afSegerstad, Y. H. (2010). Cross-cultural patterns in mobile-phone use: Public space and reachability in Sweden, the USA and Japan. New Media $\mathcal{E}$ Society, 12(1), 13-34. https://doi.org/10.1177/1461444809355111

Beland, L. P., \& Murphy, R. (2016). Ill communication: technology, distraction \& student performance. Labour Economics, 41, 61-76. https://doi.org/10.1016/j.labeco.2016.04.004

Benson, P. (2011). Language learning and teaching beyond the classroom: An introduction to the field. In P. Benson \& H. Reinders (Eds.), Beyond the language classroom (pp. 7-16). Palgrave Macmillan, London.

Benson, P., \& Voller, P. (1997). Introduction: autonomy and independence in language learning. In P. Benson \& P. Voller (Eds.), Autonomy and Independence in Language Learning. Harlow: Longman.

Camilleri, G. (1999). Learner autonomy: The teachers' views. Retrieved from http://archive.ecml.at/documents/pubCamilleriG_E.pdf 
Cavus, N., \& Ibrahim, D. (2009). M-learning: An experiment in using SMS to support learning new English language words. British Journal of Educational Technology, 40(1), 78-91. https://doi.org/10.1111/j.1467-8535.2007.00801.x

Cohen, J. (1988), Statistical Power Analysis for the Behavioral Sciences, (2 ${ }^{\text {nd }}$ ed.). Hillsdale: Lawrence Erlbaum.

Cohen, L., Manion, L., \& Morrison, K. (2011). Research methods in education (7th ed.). New York: Routledge.

Council of Europe. (2001). Common European Framework of Reference for Languages: learning, teaching, assessment. Cambridge: Cambridge University Press.

Cowan, P., \& Butler, R. (2013). Using activity theory to problematize the role of the teacher during mobile learning. SAGE Open, 3(4), 1-13. https://doi.org/10.1177/2158244013516155

Dam, L. (2011). Developing learner autonomy with school kids: Principles, practices, results. In D. Gardner (Ed.), Fostering autonomy in language learning (pp. 126-136). Gaziantep: Zirve University.

Dehkordi, E. M., \& Taki, S. (2018). Iranian male and female EFL learners` perceptions toward the use of Mobile Assisted Language Learning. Journal of Applied Linguistics and Language Research, 5(3), 56-66.

De la Fuente, M. J. (2014). Learners' attention to input during focus on form listening tasks: The role of mobile technology in the second language classroom. Computer Assisted Language https://doi.org/10.1080/09588221.2012.733710

Denscombe, M. (2014). The good research guide: For small-scale social research projects $\left(5^{\text {th }}\right.$ ed.). Maidenhead: Open University Press.

Dickinson, L. (1994). Preparing learners: Toolkit requirements for preparing/orienting learners. In E. Esch (Ed.), Self-access and the adult language learner (pp. 39-49). London: CILT.

Dickinson, L. (1995). Autonomy and motivation a literature review. System, 23(2), 165174. https://doi.org/10.1016/0346-251x(95)00005-5

Ducate, L., \& Lomicka, L. (2009). Podcasting in the language classroom: Inherently mobile or not? In R. Oxford \& J. Oxford (Eds.), Second language teaching and learning in the net generation (pp. 113-128). Honolulu: University of Hawai'i, National Foreign Language Resource Center.

Fabian, K., Topping, K. J., \& Barron, I. G. (2018). Using mobile technologies for mathematics: Effects on student attitudes and achievement. Educational Technology Research and Development, 66(5), 1119-1139. https://doi.org/10.1007/s11423-018-9580-3

Farangi, M. R., Kamyab, J., Izanlu, M., \& Ghodrat, N. (2017). The effect of using SMS as a post task activity on Iranian EFL learners' grammar knowledge. Journal of Language Teaching and Research, 8(2), 392-403. https://doi.org/10.17507/jltr.0802.24

Fredrick, L., \& Karthikeyan, J. (2018). Exploring the reach of mobile assisted language learning among mechanical engineering students. International Journal of Mechanical Engineering and Technology, 9(8), 738-742.

Hazaea, A., \& Alzubi, A. A. F. (2018). Impact of mobile assisted language learning on learner autonomy in EFL reading context. Journal of Language and Education, 4(2), 48-58. https://doi.org/10.17323/2411-7390-2018-4-2-48-58

Hijazi-Omari, H., \& Ribak, R. (2008). Playing with fire: On the domestication of the mobile phone among Palestinian teenage girls in Israel. Information, Community and Society, 11(2), 149-166. https:/ / doi.org/10.1080/13691180801934099

Holec, H. (1981). Autonomy in foreign language learning. Oxford, UK: Pergamon. 
Huang, Y. M., Jeng, Y. L., \& Huang, T. C. (2009). An educational mobile blogging system for supporting collaborative learning. Journal of Educational Technology $\mathcal{E}$ Society, 12(2).

Ivić, V., \& Jakopec, T. (2017). Using mobile application in foreign language learning: A case study. Libellarium: Journal for the Research of Writing, Books, and Cultural Heritage Institutions, 9(2), 217-230. https:/ / doi.org/10.15291/libellarium.v9i2.288

Johnson, G. M. (2007). College student internet use: Convenience and amusement. Canadian Journal of Learning and Technology,33(1), 1. https://doi.org/10.21432/t2088s

Johnson, S., \& Radhakrishnan, N. (2017). Academic use of smart phones among the students of business schools in UAE-a study. KIIT Journal of Library and Information Management, 4(1), 32-36.

Kasesniemi, E. L., \& Rautiainen, P. (2002). Mobile culture of children and teenagers in Finland. In J. Katz \& M. Aakhus, (Eds.), Perpetual contact: Mobile communication, private talk, public performance (pp. 227-241). Cambridge, MA: Cambridge University Press.

Kim, D., Rueckert, D., Kim, D. J., \& Seo, D. (2013). Students' perceptions and experiences of mobile learning. Language Learning \& Technology, 17(3), 52-73.

Kim, D., Ruecker, D., \& Kim, D. J. (2017). Mobile Assisted Language Learning Experiences. InternationalJournal of Mobile and Blended Learning, 9(1), 49-66. https:// doi.org/10.4018/ijmbl.2017010104

Krishna, V. R. (2020). Mobile assisted language learning (MALL). Unpublished manuscript.

Lachane, J. A., \& Mazzocco, M. M. (2006). A longitudinal analysis of sex differences in mathematics and partial skills in primary school aged children. Learning and Individual Differences 16(3), 195-216. https:// doi.org/10.1016/j.lindif.2005.12.001

Leis, A., Tohei, A., \& Cooke, S. (2015). Smartphone Assisted Language Learning and Autonomy. International Journal of Computer-Assisted Language Learning and Teaching (IJCALLT), 5(3), 75-88. https://doi.org/10.4018/ijcallt.2015070105

Lindlof, T. R., \& Taylor, B. C. (2002). Qualitative communication research methods. Thousand Oaks, Calif: Sage Publications.

Little, D. (1991). Learner autonomy. 1: Definitions, issues and problems. Dublin: Authentik.

Little, D. (1995). Learning as dialogue: The dependence of learner autonomy on teacher autonomy. System, 23(2), 175-181. https://doi.org/10.1016/0346-251x(95)000066

Little, D. (2007). Language learner autonomy: Some fundamental considerations revisited. International Journal of Innovation in Language Learning and Teaching, 1(1), 14-29. https://doi.org/10.2167/illt040.0

Liu, T. Y. (2009). A context-aware ubiquitous learning environment for language listening and speaking. Journal of Computer Assisted Learning, 25(6), 515-527. https:// doi.org/10.1111/j.1365-2729.2009.00329.x

Mardjuki, S. M. (2018). Learner autonomy: Gender-based perception among EFL Indonesian students. Indonesian Journal of EFL and Linguistics, 3(1), 1-17. https://doi.org/10.21462/ijefll.v3i1.46

Miliander, J., \& Trebbi, T. (Eds.). (2011). Educational policies and language learner autonomy in schools: A new direction in language education? Authentic Language Learning Resources.

Min, H., \& Borg, F. B. (2018). College English autonomous study: Teachers' beliefs and practices. Foreign Language Learning Theory and Practice, 38(2), 57-64. 
Nasr, H. A., \& Abbas, A. A. (2018). Impact of mobile assisted language learning on learner autonomy in EFL reading context. Journal of Language and Education, 4 (2), 48-58. https:// doi.org/10.17323/2411-7390-2018-4-2-48-58

Ng, S. F., Hassan, N. S. I. C., Nor, N. H. M., \& Malek, N. A. A. (2017). The relationship between smartphone use and academic performance: A case of students in a Malaysian tertiary institution. Malaysian Online Journal of Educational Technology, 5(4), 58-70.

Nunan, D. (1997). Designing and adapting materials to encourage learner autonomy. In P. Benson \& P. Voller (Eds.), Autonomy and independence in language learning (pp. 192-203). London: Longman.

Palfreyman, D., \& Smith, R. C. (2003). Learner autonomy across cultures: Language education perspectives. London: Macmillan.

Patel, C. (2013). Use of multimedia technology in teaching and learning communication skill: An analysis. International Journal of Advancements in Research $\mathcal{E}$ Technology, 2(7), 116-123.

Pollara, P., \& Broussard, K. (2011). Student perceptions of mobile learning: A review of current research. $\quad$ Retrieved from https://www.academia.edu/362094/Student_Perceptions_of_Mobile_Learning _A_Review_of_Current_Research

Purwaningrum, Y. A., \& Yusuf, N. F. (2019). Students`voice towards the integrations of MALL to promote autonomous language learning. https:// doi.org/10.1145/3323771.3323823

Rahamat, R., Shah, M. P., Din, R., Puteh, N. Sh., Aziz, A. J., Norman, H., \& Embi, A. M. (2012). Measuring learners` perceived satisfaction towards e-learning material and environment. Wseas Transactions on Advances in Engineering Education, 9(3), 72-83.

Ramamuruthy, V., \& Rao, S. (2015). Smartphones promote autonomous learning in ESL classrooms. Malaysian Online Journal of Educational Technology, 3(4), 23-35.

Roberts, C., Byram, M., Barro, A., Jordan, S., \& Street, B. (2001). Language learners as ethnographers. Clevedon: Multilingual Matters.

Sato, T., Murase, F., \& Burden, T. (2015). Is mobile-assisted language learning really useful? An examination of recall automatization and learner autonomy. In F. Helm, L. Bradley, M. Guarda, \& S. Thouësny (Eds.), Critical CALL - Proceedings of the 2015 EUROCALL Conference, Padova, Italy (pp. 495-501). Dublin: Research-publishing.net. http://dx.doi.org/10.14705/rpnet.2015.000382

Smith, S. D., Salaway, G., \& Caruso, J. B. (2009). The ECAR study of undergraduate students and information technology. Retrieved from http://www.educause.edu/library/resources/ecar-study-undergraduatestudents-andinformation-technology-2009

Stockwell, G. (2010). Using mobile phones for vocabulary activities: Examining the effect of platform. Language Learning \& Technology, 14(2), 95-110.

Sung, Y., Chang, K., \& Yang, J. (2015). How effective are mobile devices for language learning? A meta-analysis. Educational Research Review, 16, 68-84. https://doi.org/10.1016/j.edurev.2015.09.001

Tai, Y., \& Ting, Y. L. (2011). Adoption of mobile technology for language learning: Teacher attitudes and challenges. The JALT CALL Journal, 7(1), 3-18. https://doi.org/10.29140/jaltcall.v7n1.105

Tran, T. Q., \& Duong, T. M. (2018). EFL learners' perceptions of factors influencing learner autonomy development. Kasetsart Journal of Social Sciences, 41, 194-199. https://doi.org/10.1016/j.kjss.2018.02.009 
Trebbi, T. (2011). Reinforcing the what, the why and the how: challenges and change for language learner autonomy. Innovation in Language Learning and Teaching, 5(2), 101-110. https:// doi.org/10.1080/17501229.2011.577527

Uzunboylu, H., \& Ozdamli, F. (2011). Teacher perception for m-learning: scale development and teachers' perceptions. Journal of Computer Assisted Learning, 27(16), 544-556. https://doi.org/10.1111/j.1365-2729.2011.00415.x

Varol, B., \& Yilmaz, S. (2010). Similarities and differences between female and male learners: inside and outside class autonomous language learning activities. Procedia - Social and Behavioral Sciences, 3, 273-274. https://doi.org/10.1016/j.sbspro.2010.07.038

Viberg, O., \& Grönlund, ̊.. (2012). Mobile assisted language learning: a literature review. In M. Specht, M. Sharples \& J. Multisilta, (Eds.), Proceedings of the 11th International Conference on Mobile and Contextual Learning (pp. 9-16). Helsinki, Finland.

Wang, Y. S., Wu, M. C., \& Wang, H. Y. (2009). Investigating the determinants and age and gender differences in the acceptance of mobile learning. British Journal of Educational Technology, 40(1), 92-118. https://doi.org/10.1111/j.14678535.2007.00809.x

White, J., \& Mills, D. (2014). Examining attitudes towards and usage of smartphone technology among Japanese university students studying EFL. CALL-EJ, 15(2), 115.

Yunus, M. M., \& Arshad, N. D. M. (2015). ESL teachers' perceptions toward the practices and prospects of autonomous language learning. Asian Social Science, 11(2), 4151. https://doi.org/10.5539/ass.v11n2p41

Zhang, L. X., \& Li, X. X. (2004). A comparative study on learner autonomy between Chinese students and west European students. Foreign Language World, 4, 15-23.

\section{Appendix 1}

Researcher-made questions to elicit EFL learners`perceptions towards MALL

1. Have you had any previous Mobile Assisted Language Learning (MALL) experience in EFL studies?

2. How do you feel about text messaging in English vocabulary learning?

3. Do you think that the usage of text messaging in EFL classes is useful?

4. What is your idea about the future use of text messaging for English learning?

5. In your ideas, do you think classes that are using MALL are more enjoyable than those without?

6. Do you think classes that use MALL are more productive than those without?

7. Is there any problem with using text messaging in EFL classes? 